\title{
The Trematode Parasites of Fishes from the English Channel.
}

\author{
$\mathrm{By}$ \\ William Nicoll, M.A., D.Sc., M.D. \\ With Figures 1-6 in the Text.
}

IN continuation of my researches on the entozoa of British marine fishes I spent two months (August and September, 1909) at the Plymouth Marine Biological Station. By the courtesy of the Government Grant Committee of the Royal Society, a table was placed at my disposal and all expenses in connection with the investigation were defrayed.

Hitherto few observations have been made upon entozoa from fishes of the south coast. The area, however, is of considerable interest from a faunistic point of view, for it contains several species of fish which are uncommon or unknown on other parts of our coast. In addition it is richer in species than either the east or the west coast. The influx of Mediterranean forms adds further interest.

During the course of these two months 419 fish belonging to 70 species were examined. Later, further consignments were sent to me in London. These comprised an additional 56 fish with an additional 9 species. The total number with which this investigation deals is therefore 475 fish and 79 different species. Amongst these, Acanthopterygian fishes figured most largely. The various groups were represented as follows :-

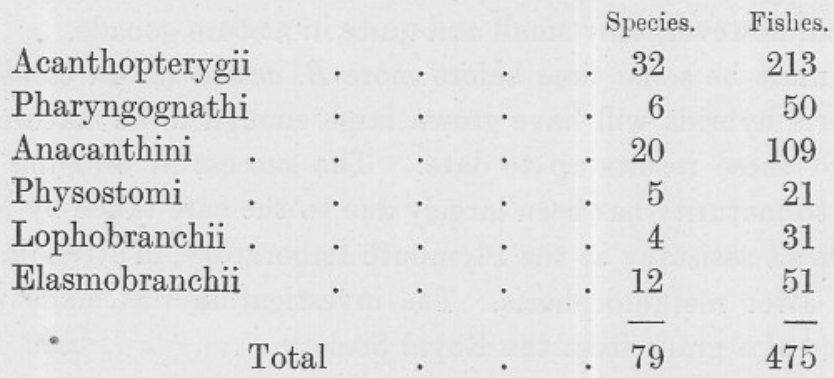

Amongst these 79 species there were 37 which I had not previously had an opportunity of examining, and the majority of them afforded interesting new records. 
Judging by those figures this is probably the largest and most representative investigation which has hitherto been made on this subject. A comparison with the numbers dealt with in my previous reports will perhaps be of interest. For St. Andrews, Millport, and Aberdeen the corresponding figures are as follows :-

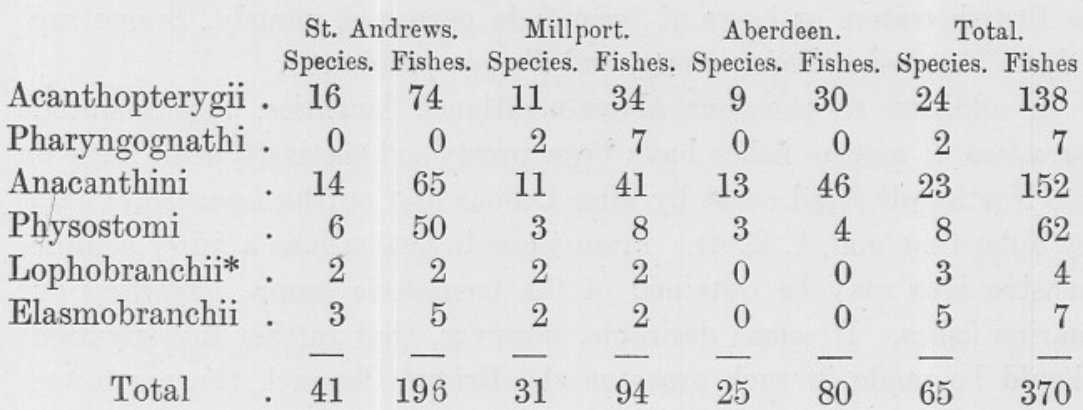

From this it is evident that the material examined at Plymouth was richer, not only in the gross total examined, but also in the variety of specimens, than the corresponding material from the other three localities combined. Of the individual groups only the Anacanthini and Physostomi were not so well represented at Plymouth as in these other localities.

In these four series of investigations I have thus examined a total of 845 fish belonging to 102 different species, giving an average of a little over 8 fish of every species. Some specimens have naturally received more attention than others, and those most exhaustively dealt with have been the sprat (Clupea sprattus), the common dab (Pleuronectes limanda), Lepadogaster gouanii, Ammodytes tobianus, the mackerel (Scomber scombrus), and the butter fish (Centronotus gunnellus). Other fishes which have received a large measure of attention have been the horsemackerel, the sea bream, the whiting, and the John Dory.

From these four localities the aggregate figures are :-

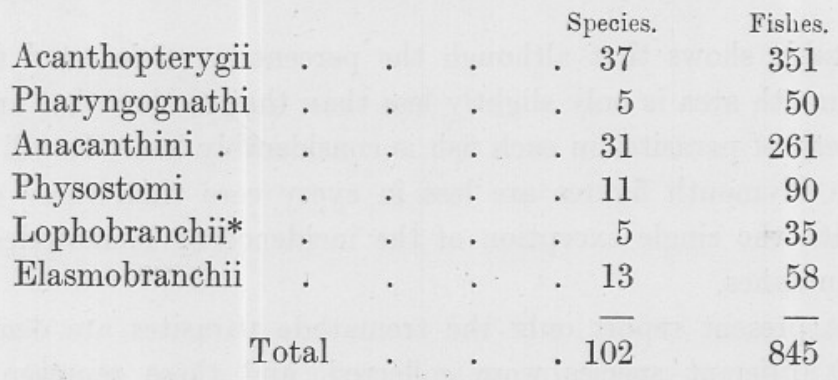

* The Sun-fish (Mola mola) is included here. 
These 102 species represent practically all the marine fishes commonly occurring in British seas. Little more than 20 others have ever been recorded from the British coasts, and the majority of those only as isolated individuals.

Apart from these investigations only four species have been recorded in British waters as hosts of trematode parasites, namely, Brama raii, Phycis blennoides, Raia radiata, and Trygon pastinacea.

In addition to the four above-mentioned localities, the trematode parasites of marine fishes have been pretty exhaustively dealt with on the Northumberland coast by Miss Lebour and on the Lancashire coast by Johnstone and A. Scott. From these investigations a fairly comprehensive idea may be obtained of the trematode fauna inhabiting our marine fishes. It seems desirable, however, that further investigations should be made in such areas as the Bristol Channel, the north-west coast of Scotland, or the Hebrides, and the southern part of the North Sea (e.g. off Lowestoft). In particular it would be interesting to obtain information as to the trematode fauna of fishes from the coast of Ireland, a region still practically untouched.

Of the 475 fishes examined at Plymouth, $380(80 \%)$ were infected with parasitic worms : $56 \%$ were infected with Trematodes, $44 \%$ with Cestodes, $48 \%$ with Nematodes, and $2 \%$ with Echinorhynchs.

It is interesting to compare these figures with those obtained in other areas. The comparison is shown in the following table :-

\begin{tabular}{|c|c|c|c|c|c|}
\hline St. Andrews & $\begin{array}{l}\text { Trematodes. } \\
\text {. } 75 \%\end{array}$ & $\begin{array}{c}\text { Cestodes. } \\
54 \%\end{array}$ & $\begin{array}{c}\text { Nematodes. } \\
67 \%\end{array}$ & $\begin{array}{c}\text { Echinorhynchs. } \\
8 \%\end{array}$ & $\begin{array}{l}\text { Total. } \\
83 \%\end{array}$ \\
\hline Millport & . $70 \%$ & $46 \%$ & $76 \%$ & $13 \%$ & $80 \%$ \\
\hline Aberdeen & . $51 \%$ & $57 \%$ & $58 \%$ & $4 \%$ & $91 \%$ \\
\hline Plymouth & . $56 \%$ & $44 \%$ & $48 \%$ & $2 \%$ & $80 \%$ \\
\hline Total & - $60 \%$ & $47 \%$ & & $5 \%$ & \\
\hline
\end{tabular}

This table shows that although the percentage of infected fishes in the Plymouth area is only slightly less than that in the other areas, yet the variety of parasites in each fish is considerably less. It will be seen that the Plymouth figures are less in every case than those of other areas with the single exception of the incidence of Trematodes in the Aberdeen fishes.

In the present report only the trematode parasites are dealt with. Over 50 different species were collected, and these represent about three-fifths of the total number of Trematodes known to occur in British 
marine fishes. The most interesting of these have already been described in a previous paper (Nicoll, 1913a).

At the end of this report a list is given of the fishes examined at Plymouth, with the trematode parasites which were obtained from them.

I have to thank Dr. E. J. Allen, Director of the Plymouth Marine Laboratory and his assistant, Mr. A. J. Smith, for their unfailing courtesy and help.

\section{LIST OF SPECIES DEALT WITH IN THIS REPORT. DIGENEA.}

DISTOMATA PROSOSTOMATA.

\section{Family ALLOCREADIIDAE.}

Sub-Family AlLocreadinae.

Genus Podocotyle (Dujardin).

1. P. atomon (Rud.).

2. P. reflexa (Crepl.).

3. P. syngnathi Nicoll.

4. P. atherinae sp. inq.

Genus Lebouria Nicoll.

5. L. varia Nicoll.

6. L. alacris (Looss).

Genus Peracreadium Nicoll.

7. P. genu (Olsson).

8. P. commune (Olsson).

Genus Cainocreadium Nicoll.

9. C. labracis (Dujardin).

Genus Helicometra Odhner.

10. H. pulchella (Rud.).

Sub-Family Stephanochasminae. Genus Stephanochasmus Looss.

11. S. pristis (Deslongch).

12. S. caducus Looss, var. lusci.

13. S. cesticillus (Molin). 
Sub-Family Lepocreadinae. Genus Lepidapedon Stafford.

14. L. rachion (Cobbold).

Genus Pharyngora Lebour.

15. P. bacillaris (Molin).

Genus Lepidauchen Nicoll.

16. L. stenostoma Nicoll.

Family FELLODISTOMIDAE.

Sub-Family Fellodistominae.

Genus Steringotrema Odhner.

17. S. cluthense (Nicoll).

18. S. divergens (Rud.).

19. S. pagelli (v. Ben.).

Genus Bacciger n.g.

20. B. bacciger (Rud.).

Sub-Family Haplocladinae.

Genus Tergestia Stossich.

21. T. laticollis (Rud.).

Family ZOOGONIDAE.

Sub-Family Zoogoninae.

Genus Zoogonoides Odhner.

22. Z. viviparus (Olsson).

Genus Zoonogenus Nicoll.

23. Z. vividus Nicoll.

Family MONORCHIDAE.

Sub-Family Monorchinae.

Genus Monorchis (Monticelli).

24. M. monorchis (Stossich).

Family HAPLOPORIDAE.

Genus Haploporus Looss.

25. H. benedeni (Stossich). 
Genus Saccocoelium Looss.

26. S. obesum Looss.

Family AZYGIIDAE.

Genus Ptychogonimus Lühe.

27. P. megastomus (Rud.).

Family HEMIURIDAE.

Sub-Family Hemiurinae.

Genus Hemiurus Rud.

28. H. communis Odhner.

29. H. ocreatus (Rud.).

Sub-Family Dinurinae.

Genus Lecithocladium Lühe.

30. L. excisum (Rud.).

Sub-Family Sterrhurinae.

Genus Lecithochirium Lühe.

31. L. rufoviride (Rud.).

Genus Synaptobothrium (v. Linstow).

32. S. caudiporum (Rud.).

Sub-Family Lecithasterinae.

Genus Lecithaster Lühe.

33. L. gibbosus (Rud.).

Sub-Family SyncoelinNaE.

Genus Derogenes Lühe.

34. D. varicus (Müller).

Genus Hemipera Nicoll.

35. H. ovocaudata Nicoll.

Genus Derogenoides Nicoll.

36. D. ovacutus Nicoll.

Family (BUNODERIDAE).

Genus Bunodera Railliet.

37. B. nodulosa (Zeder). 
Family (ACANTHOCHASIMIDAE).

Genus Acanthochasmus Looss.

38. A. imbutiformis (Molin).

DISTOMATA GASTEROSTOMATA.

Family BUCEPHALIDAE.

Sub-Family Bucephalinae.

Genus Bucephalus Baer.

39. B. minimus (Stossich)

Genus Bucephalopsis (Diesing).

40. B. gracilescens (Rud.).

Genus Rhipidocotyle Diesing.

41. R. minima (Wagener)

42. $R$. viperae (v. Ben.).

Sub-Family Prosorhynchinae.

Genus Prosorhynchus (Odhner).

43. P. crucibulum (Rud.).

44. P. aculeatus Odhner.

45. P. triglae sp. inq.

46. P. squamatus Odhner.

MONOGENEA.

Genus Microcotyle v. Ben. \& Hesse.

47. M. draconis Briot.

Genus Axine Abildgaard.

48. A. belones Abildg.

Genus Octobothrium F. S. Leuckart.

49. O. merlangi (Kuhn).

Genus 0ctocotyle Diesing.

50. O. scombri Kuhn. 
Genus Pseudocotyle v. Ben. \& Hesse,

51. P. squatinae v. Ben. \& Hesse.

Genus Calicotyle Diesing.

52. C. kroyeri Diesing.

\section{DIGENEA.}

\section{DISTOMATA PROSOSTOMATA.}

\section{Family ALLOCREADIIDAE.}

Sub-Family Allocreadinae.

Genus PODOCOTYLE (Dujardin).

Podocotyle atomon (Rud.).

Odhner, 1905, pp. 320-6.

Lebour, 1908, pp. 26-27.

This parasite was obtained from ten species of fish, namely, Gobius ruthensparri, Centronotus gunnellus, Cottus bubalis, Cyclogaster montagui, Gastraea spinachia, Gadus merlangus, Pleuronectes flesus, Zeugopterus norvegicus, Nerophis aequoreus, and Anguilla vulgaris. This is the first record of its occurrence in the pipe-fish (Nerophis).

\section{Podocotyle reflexa (Creplin).}

Odhner, 1905, p. 326.

This species was obtained from the intestine of Gastraea spinachia and Onos mustela on several occasions. It is distinguished from the previous species by its much longer cirrus-pouch and the interrupted arrangement of its yolk glands. The limits fixed by Odhner for the size of this species are too narrow, as mature specimens little over $1 \mathrm{~mm}$. in length were found in Onos mustela. It is extremely difficult to differentiate such small specimens from $P$. atomon.

Podocotyle syngnathi Nicoll.

$$
\text { Nicoll, 1913a, pp. 238-40. }
$$

This species was frequently found in the pipe-fishes, Syngnathus acus, Siphonostoma typhle and Nerophis aequoreus. 
(Podocotyle) atherinae sp. inq. (Fig. 1).

A single specimen of a species of "Podocotyle" was obtained from the anterior part of the intestine of Atherina presbyter. I am unable to refer it to any known species, and it is doubtful even if it can be included in the genus Podocotyle. It is a small, somewhat flattened form measuring $1.1 \mathrm{~mm}$. in length by $\cdot 49 \mathrm{~mm}$. in greatest breadth, and it is of a dark grey colour in life. The outline is roughly oval with a slightly attenuated neck.

The oral sucker is globular with a diameter of $\cdot 13 \mathrm{~mm}$. The ventral sucker is transversely oval and measures $\cdot 21 \times \cdot 28 \mathrm{~mm}$. The latter is

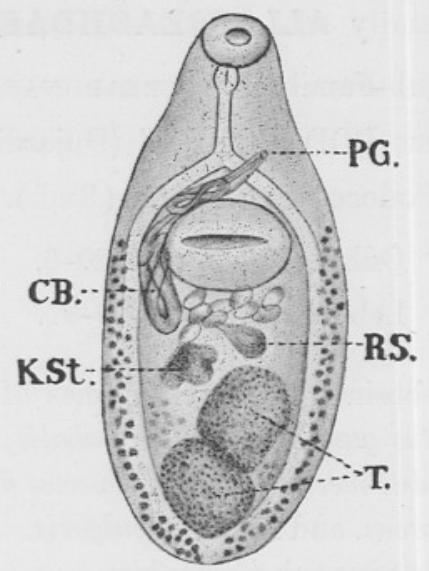

FIG. 1.-(Podocotyle) atherince. Ventral view $\times 50$. C.B. Cirrus-pouch; K.St. Ovary ; P.G. Genital aperture; R.S. Receptaculum seminis; T. Testes. G. Roberts del.

situated $46 \mathrm{~mm}$. from the anterior end. The pharynx is contiguous with the oral sucker and has a diameter of $\cdot 07 \mathrm{~mm}$. The œsophagus is $\cdot 11 \mathrm{~mm}$. long, and the wide diverticula extend nearly to the posterior end of the body.

The genital aperture is on the left side a little in front of the level of the intestinal bifurcation. The cirrus-pouch is long and slender, and reaches to the level of the ovary. It contains a long, convoluted vesicula seminalis. The ductus is simple. The testes lie near the posterior end of the body. The distance between the posterior testis and the tip of the tail being $\cdot 13 \mathrm{~mm}$. They are contiguous and oblique, the anterior being on the left. Their outline is irregularly globular, and their margins are entire. The posterior testis lies closely apposed to the right intestinal diverticulum, while the anterior one is apposed to the left diverticulum. Their greatest diameter is about $\cdot 17 \mathrm{~mm}$. 
The ovary lies to the right of the anterior testis and a little in advance of it, the two being almost contiguous. It is a distinctly trilobate body, the lobes being directed backwards, and its greatest diameter is $\cdot 13 \mathrm{~mm}$. It is separated from the ventral sucker by a space of $\cdot 14 \mathrm{~mm}$. The medium-sized, pear-shaped receptaculum seminis lies immediately in front of the anterior testis. The yolk glands are moderately developed. They are almost entirely marginal, their anterior limit being the level of the ventral sucker. They fill up a considerable part of the post-testicular space, but do not unite. Behind the ovary a few follicles are found on the inner side of the right intestinal diverticulum, while on the left a few are found internal to the diverticulum on the level of the posterior testis. The scanty ova measure $\cdot 069-\cdot 072 \times \cdot 036 \mathrm{~mm}$., and are provided with a minute knob-like process at their anopercular pole.

In referring this form to the genus Podocotyle rather than to any of the other genera of the sub-family one is influenced by the characteristic shape of the ovary, the position of the genital aperture and the length of the cirrus-pouch. The position of the testes is the chief contradictory feature, and in this respect the species bears a closer resemblance to Lebouria. It might be suggested that it is an abnormal specimen of $P$. atomon in which the testes have become displaced, but as I have no previous experience of such an abnormality I am very doubtful if this could be the case.

Genus LEBOURIA Nicoll.

\section{Lebouria alacris (Looss). \\ Nicoll, 1910, pp. 332-4.}

This species was frequently obtained from the smaller Labridae (Ctenolabrus rupestris, Centrolabrus exoletus and Crenilabrus melops). A single specimen was also found in the intestine of Labrus berggylta.

\section{Lebouria varia Nicoll.}

Nicoll, 1910, pp. 329-32.

This species was only met with in the dragonet (Callionymus lyra), in which it is fairly common.

Genus PERACREADIUM Nicoll.

Peracreadium commune (Olsson).

Nicoll, 1910, pp. 328-9.

Only three specimens of this species were met with in Labrus berggylta and Crenilabrus melops. They agree with my previous description, except 
that the ventral sucker is somewhat larger and more globular than in the Clyde specimens. It is thus not a feature to distinguish this species from P. genu.

\section{Peracreadium genu (Rud.).}

Nicoll, 1910, pp. 326-8.

This was obtained twice from the intestine of Labrus berggylta, but never from any of the other Labridae (over 30 were examined). A single immature specimen, however, occurred in the intestine of a shanny (Blennius pholis). It was only $4 \mathrm{~mm}$. long. The testes were oblique, and the ovary on the right side of the anterior testis. The cirrus-pouch reached almost to the ovary. The yolk glands were not visible, and there were no ova. It seemed impossible to determine whether this specimen should be regarded as $P$. genu or $P$. commune, but in any case it must be regarded as an adventitious parasite of the shanny.

\section{Genus CAINOCREADIUM Nicoll. \\ Cainocreadium labracis (Dujardin). Johnstone, 1908, pp. 44-53.}

Half a dozen specimens of this species were taken from the intestine of the only bass (Labrax lupus) examined.

Genus HELICOMETRA Odhner.

Helicometra pulchella (Rud.).

This was by far the commonest member of the Allocreadiidae met with. As a parasite of littoral fishes it largely replaces Podocotyle atomon, which is predominant on the east coast. At Plymouth it was met with in twelve different hosts: Serranus cabrilla, Trigla pini, Gobius paganellus, Blennius pholis, Blennius gattorugine, Lepadogaster gouanii, Labrus mixtus, Labrus berggylta, Ctenolabrus rupestris, Zeugopterus punctatus, Anguilla vulgarus and Conger conger. Ninety specimens of these fishes were examined, and the parasite was met with thirty-three times (i.e. 3 in 8). Its chief hosts are the goby and the blennies. In these it occurred three times in five.

A fairly full description, partly based on the material collected at Plymouth, has already been given (Nicoll, 1910, pp. 335-40). The distribution of this species is rather noteworthy. It has been recorded from the Mediterranean, from the English Channel and from the vest coast of Scotland. It has never been recorded from the North Sea.

H. pulchella (Rud.) of Odhner (1902) from Northern fishes, is probably a distinct species. 
Sub-Family Stephanochasminae.

Genus STEPHANOCHASMUS Looss.

\section{Stephanochasmus caducus Looss var. lusci.}

Numerous young specimens of a parasite which I can only with some doubt identify as this species were taken on two occasions from the duodenum and pyloric caeca of Gadus luscus. A single immature specimen was also found in the caeca of Gadus minutus.

They measure 1.5-3 mm. in length, and most of those over $2 \mathrm{~mm}$. contained ova. The cephalic spines are arranged in two rows of 25 each, and those of the anterior row are shorter than those of the posterior row, $.019 \mathrm{~mm}$. and $.021 \mathrm{~mm}$. respectively. In a $3 \mathrm{~mm}$. species the oral sucker has a diameter of $\cdot 12 \mathrm{~mm}$. and the ventral $\cdot 14 \mathrm{~mm}$. The latter is situated $.63 \mathrm{~mm}$. from the anterior end. The prepharynx is $.21 \mathrm{~mm}$. long, and the pharynx measures $\cdot 1 \times \cdot 08 \mathrm{~mm}$.

The cirrus-pouch extends $49 \mathrm{~mm}$. behind the ventral sucker. The vagina joins it behind the sucker, and the genital sinus is $\cdot 2 \mathrm{~mm}$. long. The ovary, testes and yolk glands are situated as described by Looss, but the yolk glands extend forward a short distance in front of the end of the cirrus-pouch. The few ova measure $\cdot 066 \times \cdot 036 \mathrm{~mm}$.

The chief respects in which these specimens differ from Looss's description (1901, p. 603) are the number and size of the cephalic spines, the position of the ventral sucker, the inequality of the suckers and the greater extent of the yolk glands. It seems possible to ascribe the first two of these to difference in age and size of the specimens (Looss's description was from specimens over $4 \mathrm{~mm}$. long). The other two features, together with the difference in number of the cephalic spines, do not seem of sufficient importance to warrant establishing a new species, but it seems advisable to regard this form as a distinct variety.

It is interesting to note that the specimen obtained by Miss Lebour (1908, p. 36) from the whiting (Gadus merlangus) does not entirely agree with Looss's description of $S$. caducus. The suckers are nearly twice as great as those of Looss's form. The yolk glands are more extensive and the eggs are larger. It is possible that this may represent a third variety of the same species.

\section{Stephanochasmus cesticillus (Molin).}

$$
\text { Looss, 1901, pp. 598-9. }
$$

Four specimens of this parasite were collected from the stomach and intestine of Zeus faber. This is the first and only time this parasite has 
been recorded from British waters, and it is the only occasion on which it has been met with in this host.

Sub-Family Lepocreadinae.

Genus LEPIDAPEDON Stafford.

Lepidapedon rachion (Cobbold).

Odhner, 1905, pp. 332-7 (Lepodora rachiaea).

Lebour, 1908, pp. 29-30.

This was found frequently in the intestine of the pollack (Gadus pollachius) once in considerable numbers. It was not met with in any of the other Gadoids, of which nearly 40 were examined.

\section{Lepidauchen stenostoma Nicoll.}

Nicoll, 1913a, pp. 240-1.

Two specimens were obtained from the intestine of Labrus berggylta. This species has already been fully described.

\section{Genus PHARYNGORA Lebour. \\ Pharyngora bacillaris (Molin). \\ Nicoll, 1910, pp. 341-7.}

This parasite was met with very frequently in the intestine of Scomber scombrus, Gadus merlangus, Capros aper and Cyclopterus lumpus. Only one specimen of the last-mentioned fish was examined (22nd April, 1910), and it contained several thousand immature specimens ranging in length from $.6 \mathrm{~mm}$. to $1.8 \mathrm{~mm}$. I have previously recorded the occurrence of this parasite in the lumpsucker caught in St. Andrews Bay (1909, p. 22, Distomum sp.). In that case, too, the parasites were all immature, though very much fewer in number. In Capros aper, also, although I have found the parasite in moderate numbers on four occasions, they have always been immature. Only in the mackerel and whiting have fully mature specimens been obtained. The mackerel is undoubtedly the commonest host of this parasite.

\section{Family FELLODISTOMIDAE.}

Sub-Family Fellodistominae.

Genus STERINGOTREMA Odhner.

Steringotrema cluthense (Nicoll).

Nicoll, 1909, pp. 472-5.

This species was the commonest member of the family Fellodistomidae 
found on the south coast, and indeed the only one met with in Pleuronectid fishes. It was found in five out of thirteen specimens of Pleuronectes limanda and $P$. microcephalus. It has already been recorded in the

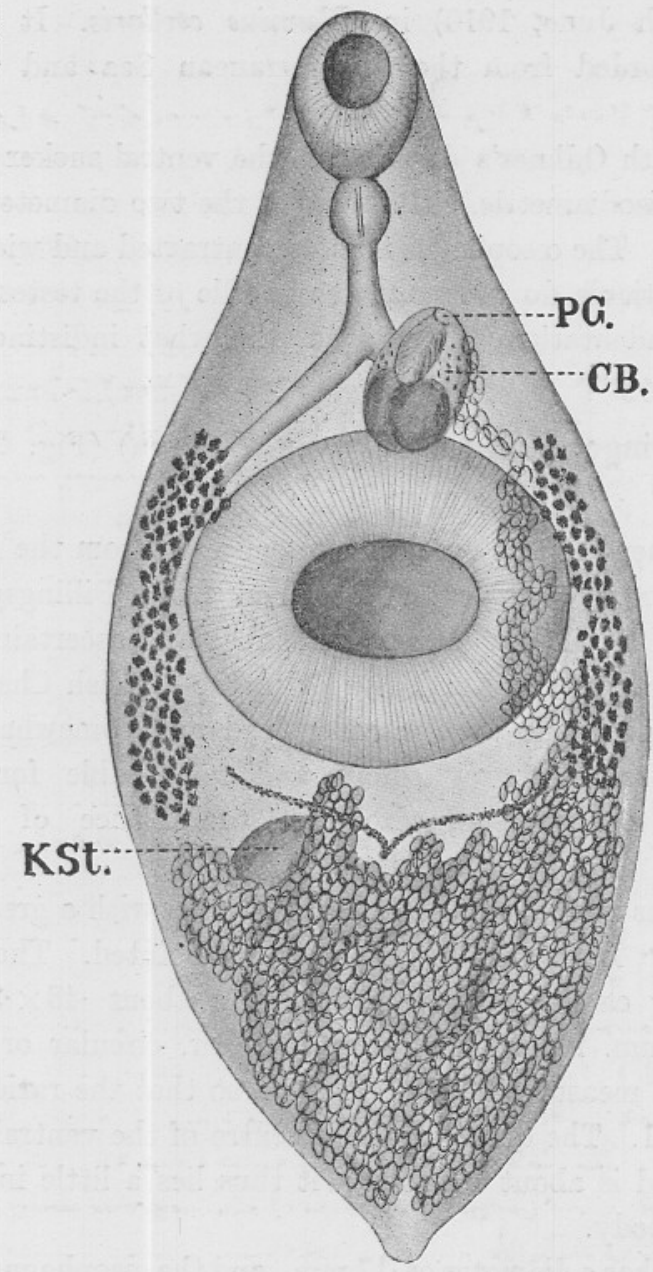

FIG. 2. - Steringotrema pagelli. Ventral view $\times 33$. C.B. Cirrus-pouch; K.St. Ovary ; P.G. Genital aperture. M. Rhodes del.

latter host from the Firth of Clyde, but it is worthy of note that it has not been met with in the North Sea, although over 100 specimens of these two hosts have been examined. It has already been fully described. 


\title{
Steringotrema divergens (Rud.).
}

\author{
Odhner, 1911, p. 103.
}

This species was met with in fairly large numbers on two occasions (15th and 24th June, 1910) in Blennius ocellaris. It has hitherto only been recorded from the Mediterranean Sea and only in this host.

Compared with Odhner's description the ventral sucker in my specimens is less anisodiametric. The ratio of the two diameters being $6: 7$ instead of $6: 8$. The œesophagus is more contracted and wider, while the intestinal diverticula do not reach the middle of the testes. The ovary shows slight indentation, giving it a somewhat indistinctly trilobate appearance.

\section{Steringotrema pagelli (van Beneden) (Fig. 2). Odhner, 1911, p. 102.}

A few specimens of this species were collected from the intestine of a sea-bream (Sparus centrodontus) obtained from Billingsgate Market, London (19th June, 1912). It was not possible to ascertain whether the fish was captured in the North Sea or in the English Channel. When collected the specimens were already dead and somewhat macerated. They were of a dull grey colour and remarkable for their great thickness and the unusual size and prominence of the ventral sucker.

The specimens measure $3 \cdot 6-4 \cdot 1 \mathrm{~mm}$. in length with a greatest breadth of $1.6-1.8 \mathrm{~mm}$. Both ends of the body are pointed. The oral sucker, which in every case is elongated, measures about $\cdot 48 \times \cdot 39 \mathrm{~mm}$. in a specimen $3.8 \mathrm{~mm}$. long. The ventral sucker, circular or transversely oval in outline, measures $1.05 \times 1.16 \mathrm{~mm}$., so that the ratio is not quite as much as $3: 1$. The distance of the centre of the ventral sucker from the anterior end is about $1.8 \mathrm{~mm}$. ; it thus lies a little in front of the middle of the body.

The pharynx has a diameter of $\cdot 17 \mathrm{~mm}$., and the cosophagus is somewhat longer. The intestinal diverticula diverge widely. Their ends are obscured by the great mass of ova.

The ovary and testes are also almost completely hidden by the uterus. The cirrus-pouch is a long bulbous structure lying immediately in front of the ventral sucker, which it touches. The aperture is on the level of the intestinal bifurcation and about midway between it and the left margin of the body. The vesicula seminalis is of comparatively large size. 
The yolk glands are situated at the sides of the ventral sucker and extend a short distance both in front of and behind it. Their extent is more limited than in S. cluthense. The uterus is very firmly packed and fills almost the whole of the post-acetabular region. The ova have thick brown shells and measure $\cdot 057-\cdot 063 \times \cdot 033-.037 \mathrm{~mm}$. Their measurements are considerably larger than those found by Odhner for the same species.

Genus BACCIGER n.g.

Bacciger bacciger (Rud., Stoss., 1889) (Fig. 3).

On two occasions a single specimen of a small distome was found in the stomach of Atherina presbyter. The fish were received in London

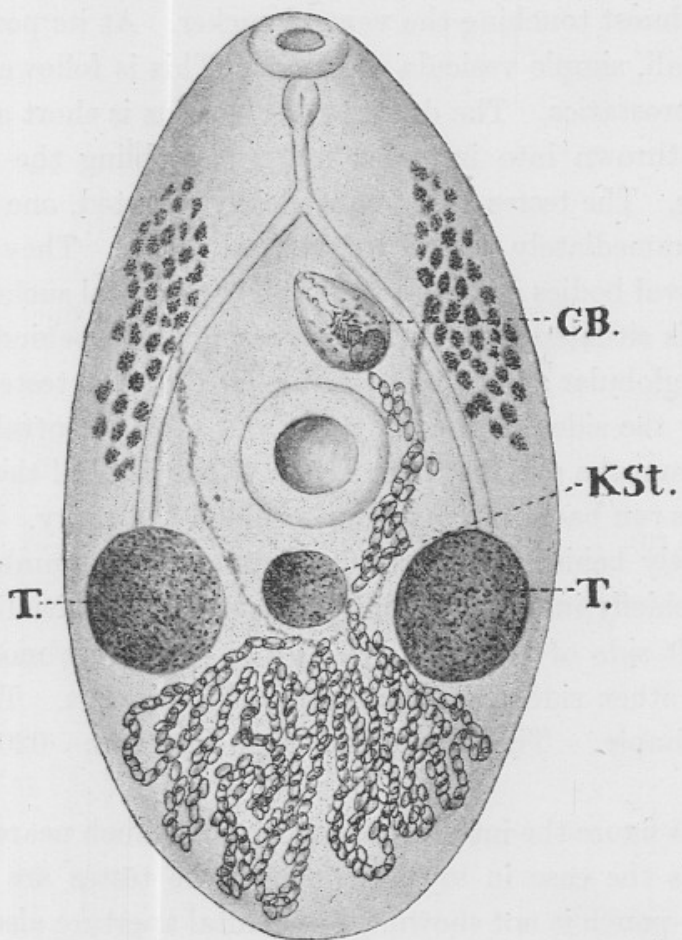

Fig. 3.-Bacciger bacciger. Ventral view $\times 100$. C.B. Cirrus-ponch; K.St. Ovary ; T. Testes. G. Roberts del.

from Plymouth, and on that account the viscera were somewhat decomposed and the parasites badly preserved. From what could be made out of their anatomy, however, they appear to be either identical with or very closely related to Distomum baccigerum (Rud.) Stossich from Atherina hepsetus.

NEW SERIEs,-VoL. $x$. No. 3. OCTOBER, 1914. 
The body is flat and of oval outline. The cuticule is unarmed. The length of the body (slightly pressed) is $.95 \mathrm{~mm}$., and the maximum breadth in the middle, $.52 \mathrm{~mm}$. The sub-terminal oral sucker has a diameter of $105 \mathrm{~mm}$., and the ventral sucker, situated a little in front of the middle of the body, measures $\cdot 15 \mathrm{~mm}$. There is a small pharynx, contiguous in the oral sucker. The œsophagus is two or three times as long as the pharynx, the intestinal bifurcation taking place about midway between the pharynx and the genital aperture. The intestinal diverticula are very narrow, they extend into the posterior part of the body, but their termination is obscured by the uterus.

The genital aperture is median, and lies about $\cdot 15 \mathrm{~mm}$. in front of the ventral sucker. There is a small, stout cirrus-pouch lying entirely in front of but almost touching the ventral sucker. At its posterior end it contains a small, simple vesicula seminalis. This is followed by a short inflated pars prostatica. The ductus ejaculatorius is short and wide and its walls are thrown into irregular folds, resembling the condition in Steringophorus. The testes are symmetrically situated, one on each side of the body, immediately behind the ventral sucker. They are globular or elongated oval bodies a little larger than the ventral sucker.

The ovary is situated between the testes, directly behind the ventral sucker. It is globular and somewhat smaller than the testes. The yolk glands occupy the sides of the body in front of the ventral sucker, and they extend from the middle of the sucker to the level of the œsophagus. The yolk ducts run backwards and unite behind the ovary. The uterus is confined entirely behind the testes. It forms a large number of narrow convolutions chiefly in a longitudinal direction. The initial convolutions are on the left side of the body, where the eggs are almost colourless. Towards the other side the colour gradually deepens. The vagina is apparently simple. The numerous eggs measure $\cdot 020-\cdot 024 \times \cdot 014$ $.017 \mathrm{~mm}$.

In Stossich's figure the intestinal bifurcation is much nearer the ventral sucker than is the case in my specimens; the testes are much larger and the cirrus-pouch is not shown. The genital aperture also is described as being immediately behind the pharynx. How far these discrepancies are due to errors of observation it is impossible to say, as I have had no opportunity of examining Stossich's original material.

This species undoubtedly represents the type of a distinct genus of the family FELLODISTOMIDAE and the sub-family FeLLODISTOMINAE. Its general build rather suggests an affinity with the Monorchidae, but the structure of the cirrus-pouch and vagina excludes it from that family. 
Sub-Family Haplocladinae.

Genus TERGESTIA Stossich.

Tergestia laticollis (Molin).

Odhner, 1911, p. 111-13; Nicoll, 1913b, pp. 192-3.

This species was found frequently in the intestine of the horse-mackerel (Trachurus trachurus). It occurs occasionally in fairly large numbers, though as a rule only a few specimens are present in one host. It appears to be an exclusive parasite of this host.

\section{Family ZOOGONIDAE.}

Sub-Family Zoogoninae.

Genus ZOOGONOIDES Odhner.

Zoogonoides viviparus (Olsson).

Odhner, 1902a, p.'62; Nicoll, 1907, p. 83.

This very common parasite has already been recorded ${ }^{\boldsymbol{\nabla}}$ from eight species of British fishes. An additional five have here to be noted, namely, Zeus faber, Blennius gattorugine, B. ocellaris, Solea vulgaris, S. variegata. It was also found in Callionymus lyra, Pleuronectes limanda, $P$. microcephalus and $P$. platessa. The chief hosts of this parasite are undoubtedly Callionymus lyra, Pleuronectes spp. and Solea spp. It is rather curious that it has never once been recorded from Gadoid fishes or from the Labridae. It is worth remarking that the specimens I obtained from the cat-fish (Anarrhichas lupus) at St. Andrews belong to this species and not to the more recently discovered $Z$. subaequiporus Odhner, from the same host.

\section{Genus ZOONOGENUS Nicoll.}

\section{Zoonogenus vividus Nicoll.}

Nicoll, 1912, pp. 200-2.

A species which I have already described was met with frequently in the intestine of Sparus centrodontus. As I have previously remarked, it is an extremely delicate species and exceedingly difficult to preserve in a satisfactory state. An additional six bream obtained from Billingsgate Market were examined in June, 1912, but they were not infected.with the parasite. 


\section{Family MONORCHIDAE.}

Sub-Family Monorchinae.

Genus MONORCHIS Monticelli.

Monorchis monorchis (Stossich).

Looss, 1902b, pp. 117-18.

A couple of specimens of this parasite were found in the intestine of Blennius gattorugine.

\section{Family HAPLOPORIDAE.}

Genus SACCOCOELIUM Looss.

\section{Saccocoelium obesum Looss.}

Looss, 1902a, pp. 140-1.

A few specimens of this parasite were found in the intestine of a grey mullet (Mugil chelo).

\section{Genus HAPLOPORUS Looss.}

\section{Haploporus benedeni (Stossich).}

Looss, 1902a, pp. 136-8.

A few specimens were obtained from the intestine of a grey mullet (Mugil chelo) along with specimens of Saccocoelium obesum.

\section{Family AZYGIIDAE.}

Genus PTYCHOGONIMUS Lühe. Ptychogonimus megastomus (Rud.). Jacoby, 1899, pp. 16-24 ; Jägerskiöld, 1900, pp. 68-74.

This parasite was obtained from the stomach of four out of six specimens of Mustelus vulgaris. It usually occurred in moderate numbers.

\section{Family HEMIURIDAE.}

Sub-Family Hemiurinae.

Genus HEMIURUS (Rud.).

\section{Hemiurus communis Odhner.}

Odhner, 1905, p. 351 ; Lebour, 1908, p. 46.

This exceedingly common and widespread fish parasite was met with in sixteen different species of fish, namely, Sparus centrodontus, Capros aper, Lophius piscatorius, Cottus bubalis, Trigla pini, T. gurnardus, Gobius paganellus, Lepadogaster gouanii, Gadus luscus, G. merlangus, G. minutus, G. pollachius, Ammodytes lanceolatus, Molva molva, Zeugop- 
terus punctatus and Nerophis aequoreus. The species is now known to occur in thirty species of British marine fishes, and it is, with the exception of Derogenes varicus, the most widely distributed of all British fish parasites. In the above list the bream (Sparus centrodontus) from which the parasites were obtained were bought in the London market, so that their actual origin is unknown. None of the bream examined at Plymouth harboured the parasite.

Although so widely distributed, the parasite shows a distinct preference for Gadoid fishes, of which eleven species have been found to harbour it. I have myself examined over 120 Gadoids and found the parasite in $34 \%$ of them. Amongst the total number of other fishes which I have examined it has been present in less than $5 \%$. Next to the Gadoids, Cottus bubalis and Hippoglossus vulgaris are probably the most frequent hosts.

\section{Hemiurus ocreatus (Rud.). \\ $=$ H. LUHEI Odhner.}

Odhner, 1905, p. 352 ; Nicoll, 1909, pp. 21-2.

By far the commonest host of this parasite was found to be the pilchard (Clupea pilchardus). It was also met with on one occasion in each of the following hosts: Trachurus trachurus, Capros aper, Scomber scombrus, Gadus merlangus, and G. pollachius.

\section{Sub-Family (Dinurinae). Genus LECITHOCLADIUM Lühe. \\ Lecithocladium excisum (Rud.).}

Looss, 1907, pp. 131-2.

This species was found only in the stomach of the mackerel (Scomber scombrus). It occurred in three out of eight specimens examined.

\section{Sub-Family Sterrhurinae. \\ Genus LECITHOCHIRIUM Lühe. \\ Lecithochirium rufoviride (Rud.). \\ Looss, 1907, p. 147.}

This was found in the stomach of the common eel (Anguilla vulgaris), the conger (Conger conger) and the angler (Lophius piscatorius). It is an extremely common parasite of the first two fishes, but has not previously been recorded from Lophius. Looss regards the conger as the only authentic host of the parasite, but there is no doubt that the single 
specimen I have obtained from Lophius really belongs to this species. It is about $5 \mathrm{~mm}$. in length and has suckers measuring respectively $\cdot 65 \mathrm{~mm}$. and $.78 \mathrm{~mm}$. in diameter.

The encysted stage of this parasite was met with frequently in the shanny (Blennius pholis). It occurred in fairly large opaque brown cysts measuring $\cdot 7-1.4 \mathrm{~mm}$. in diameter. They were attached to various abdominal viscera, but chiefly the intestine and the liver. They were commonest in the intestinal wall, either loosely attached or firmly embedded, and in more than one case free larvæ were found actually in the intestine. The larvæ when freed from the cyst were about $2 \mathrm{~mm}$. in length (ecsoma retracted), and they had suckers measuring $\cdot 28 \mathrm{~mm}$. and $.4 \mathrm{~mm}$. respectively in diameter. The genital organs were well developed and fairly numerous eggs were present in many. These measured $.015 \times .009 \mathrm{~mm}$.

The occurrence of the larvæ of Lecithochirium gravidum encysted in pipe-fishes has already been recorded by Looss (1907, p. 148).

\section{. Genus SYNAPTOBOTHRIUM von Linstow. Synaptobothrium caudiporum (Rud.). Looss, 1907, pp. 150-2.}

This parasite has not hitherto been recorded from British waters. It occurred in the stomach of three out of five specimens of Trigla hirundo and once in Zeus faber and Lophius piscatorius. The specimens are considerably larger than those examined by Looss, reaching a length of $4 \mathrm{~mm}$. (unpressed specimens) or $5 \mathrm{~mm}$. (pressed specimens). The vesicula seminalis is confined entirely in front of the ventral sucker, while the metraterm may reach the centre of the sucker. The eggs have the characteristic shape described by Looss.

Encysted larvæ of this specimen were found along with those of Lecithochirium rufoviride in the liver and intestinal wall of a small specimen of Labrus berggylta, and two cysts were found in the intestinal wall of Crenilabrus melops.

Sub-Family Lecithasterinae.

Genus LECITHASTER Lühe.

Lecithaster gibbosus (Rud.).

Looss, 1907, p. 164 ; Odhner, 1905, pp. 356-8; Nicoll, 1909, pp. 18-20.

This parasite occurred in seven different hosts, namely, Serranus cabrilla, Trachurus trachurus, Zeus faber, Trachinus vipera, Trigla pini, 
Gadus merlangus, and Zeugopterus norvegicus. Though fairly widespread, it is by no means a common parasite, and its numbers in any particular host rarely exceed two or three.

Sub-Family Syncoelinnae.

Genus DEROGENES Lühe.

Derogenes varicus (O. F. Müller).

Odhner, 1905, pp. 360-4 ; Johnstone, 1907, pp. 188-92 ;

Lebour, 1908, pp. 45-6.

By far the commonest of marine fish parasites, this species was found in the stomach of twenty-eight different hosts, namely, Mullus barbatus, Sparus centrodontus, Trachurus trachurus, Capros aper, Zeus faber, Trachinus vipera, T. draco, Lophius piscatorius, Cottus bubalis, Agonus cataphractus, Callionymus lyra, Trigla pini, T. gurnardus, T. hirundo, Cyclopterus lumpus, Blennius ocellaris, Gadus luscus, G. minutus, G. merlangus, G. pollachius, Molva molva, Onos tricirratus, Bothus maximus, Pleuronectes flesus, P. limanda, Solea vulgaris, Salmo trutta, and Conger conger.

Genus HEMIPERA Nicoll.

Hemipera ovocaudata Nicoll.

Nicoll, 1913a, pp. 242-3.

This species was found a few times in the stomach of Lepadogaster gouanii.

\section{Genus DEROGENOIDES Nicoll.}

\section{Derogenoides ovacutus Nicoll.}

Nicoll, 1913a, pp. 243-6.

This parasite was met with only once in the stomach of a weever, Trachinus draco.

\section{Family BUNODERIDAE.}

Genus BUNODERA Railliet.

Bunodera nodulosa (Zeder).

Looss, 1894, pp. 33-41.

A few specimens of this species were obtained from the intestine of a trout (Salmo trutta) from the River Yealm. 


\section{Family ACANTHOCHASMIDAE.}

\section{Genus ACANTHOCHASMUS Looss.}

Acanthochasmus imbutiformis (Molin).

Looss, 1901, pp. 632-3 ; Johnstone, 1906, pp. 177-9.

About thirty specimens of this parasite were found in the intestine of Labrax lupus.

What appears to be the larval stage of this parasite was found encysted in the gills of the pipe-fish, Siphonostoma typhle. A single cyst containing a living larva was also found on one occasion amongst the stomach contents of a whiting (Gadus merlangus).

The cysts in the gills of Siphonostoma are oval and measure $\cdot 3-\cdot 65 \mathrm{~mm}$. in length. The oral sucker is slightly larger than the ventral, and is surrounded by eighteen cephalic spines. The cyst in the whiting had a diameter of $.38 \mathrm{~mm}$. and the cercaria a length of $1.5 \mathrm{~mm}$. The oral sucker measured $\cdot 15 \mathrm{~mm}$. and the ventral $\cdot 17 \mathrm{~mm}$. The cephalic spines numbered sighteen and measured $.056 \mathrm{~mm}$. in length.

\section{GASTEROSTOMATA.}

Of this sub-order eight different species were collected, only one of which appears to be hitherto undescribed. A remarkable feature of this group is the great variation in the anatomical topography which may occur, even within specific limits. This variation affects chiefly the position of the genital glands and of the mouth. The size of the excretory vesicle also varies considerably. On the other hand, the position of the yolk glands and the size of the cirrus-pouch are fairly constant.

The variation is particularly well illustrated in the case of Prosorhynchus crucibulum (Rud.), in which as regards the position of the genital glands no two descriptions have yet agreed. It has been pointed out (Nicoll, 1910) that these discrepancies are due to the extreme variation in the position of the genital glands in this species. A similar, but less extensive, variation is found in Prosorhynchus aculeatus Odhner.

Within generic limits a still wider variation may be observed. In illustration it is sufficient to compare the condition in Prosorhynchus squamatus Odhner with that in $P$. aculeatus. In the former the ovary and testes lie almost directly one behind the other, along the right margin of the middle part of the body. In P. aculeatus, on the other hand, they are disposed in a triangle in the posterior part of the body, the ovary being in front and the testes lying one on each side of the body. 
In the prosostomate distomes we are accustomed to regard the relative position of the genital glands as constant within narrow limits for the same species, and any such difference as exists between $P$. squamatus and $P$. aculeatus would be sufficient to warrant generic separation. In the Gasterostomata, however, it is evident that one cannot regard this feature as a satisfactory basis of classification, and recourse must be had to others of a more constant nature. Odhner has already (1905) denoted the chief of these, namely, the structure of the copulatory organs, the structure of the head and the disposition of the yolk glands.

Apart from the situation of the genital glands and the configuration of the uterus, the species included in the genus Prosorhynchus appear to form a homogeneous group. The same, however, cannot be said with regard to the remaining species of Gasterostomes, included by Odhner under the genus Gasterostomum (=Bucephalus).

They all agree in having the yolk glands arranged in two distinct groups, which are usually marginal in position, and, so far as is known, the structure of the copulatory organs does not vary very much from the type found in Bucephalus polymorphus (=Gasterostomum fimbriatum). It is in the structure of the anterior end that we meet with the most pronounced features of difference. Three main types may be recognised. (1) The anterior end may be provided with a simple sucker as in Gasterostomum gracilescens and $G$. tergestinum. This sucker closely resembles the ventral sucker of the prosostomate distomes, and is regarded by Odhner as the primitive type of head structure in the Gasterostomes. (2) From the sucker muscular prolongations may grow out in the form of tentacles or fimbriae as in G. fimbriatum and G. minimum Stossich. (3) The sucker may degenerate in musculature, become very shallow and be surmounted by a contractile fan-shaped hood as in G. triglae and G. viperae. It is apparent that some generic separation of these three groups is desirable, and it is only on the structure of the anterior end that this is practicable. Each of these three groups has already, in earlier literature, been regarded as of generic or at least subgeneric importance. The synonymy is slightly complicated.

The monotypical genus Gasterostomum was founded on $G$. fimbriatum, and as this has been shown to be the adult of the earlier known Bucephalus polymorphus the name Gasterostomum fimbriatum must be regarded as nomen nudum and the genus Gasterostomum as a synonym of Bucephalus.

In 1855 Diesing erected the sub-genus Bucephalopsis for the larval form $B$. haimeanus, and this has been shown to be the larva of Gasterostomum gracilescens (Rud.). This species is undoubtedly the type of a 
distinct genus, and on that account I propose to raise the sub-genus Bucephalopsis to generic rank with B. gracilescens (Rud., 1819) as type.

A complication enters here, however, for in 1858 Diesing erected the genus Rhipidocotyle for the reception of the two species $G$. gracilescens and G. minimum Wagener (nec. Stossich) without designating the type. Stiles \& Hassall (1908) have tentatively taken G. gracilescens as the type of this genus, but, as I shall show, G. minimum Wagener is undoubtedly the real type of this genus.

I am, unfortunately, not personally familiar with Wagener's original specimens, nor have I had an opportunity of examining any Gasterostomes from the type host, Trigla microlepidota, but a careful study of Wagener's original figure (1852) has suggested to me that G. minimum Wagener is identified with $G$. triglae van Beneden, 1870, and with the form which I have described under that name (1909). The most characteristic feature of this species is the highly contractile fan-shaped structure which surmounts the anterior sucker. To both Wagener and van Beneden this structure must have appeared in a very contracted condition and so have escaped observation. Diesing, however, must have been familiar with it and have been influenced by it in his choice of a generic name, hence the highly descriptive combination Rhipidocotyle ( $\hat{\rho} \hat{i} \pi i_{\varsigma}, \hat{\rho} \hat{\imath} \pi \hat{\imath} \delta o \varsigma=\mathrm{a}$ fan, $\kappa о \tau \tilde{v} \lambda \eta=$ a cup). No more appropriate term could have been invented. At the same time it is remarkable that Diesing should have included in the same genus $G$. gracilescens, which possesses no such fan-shaped structure.

There is nothing in the remaining anatomy of either of these species which to my mind bears the slightest resemblance to a fan, and on that account I am convinced that it was the fan-shaped cephalic hood which Diesing regarded as the distinctive feature of this genus. It will thus be necessary to revive the old generic term which Odhner (1905, p. 296, note 3 ) somewhat cavalierly consigned to the "lumber room of useless names."

As Gasterostomum has become a nomen nudum the family name Gasterostomidae must be replaced by Bucephalidae, and this family will now include the genera Bucephalus Baer, 1827, Bucephalopsis (Diesing, 1855), Rhipidocotyle Diesing, 1858, and Prosorhynchus Odhner, 1905. As Odhner has already suggested, a further separation of these genera appears advisable. I propose to separate them into two sub-families, Bucephatinae, n. subfam. and Prosorhynchinae, n. subfam.

The definitions of these sub-families are identical with the definitions given by Odhner (1905, pp. 296-7) for the genera Gasterostomum and 
Prosorhynchus respectively. Bucephalinae includes the genera Bucephalus, as type, Bucephalopsis and Rhipidocotyle.

The definition of these three genera may be summed up briefly as follows :-

Bucephalus Baer, 1827.

Bucephatinae in which the anterior end is provided with a muscular sucker around which are a number of muscular retractile tentacles or fimbriae. Type: B. polymorphus Baer, 1827 (=Gasterostomum fumbriatum v. Siebold, 1848) B. minimus (Stossich) (Gasterostomum minimum Stossich, 1887, nec. Wagener, 1852) may also be included in this genus.

Gasterostomum gorgon Linton, 1905, may be provisionally included here, but will probably require to be regarded as the type of a distinct genus. The "Gasterostomum sp." depicted by Linton (1910, Fig. 225) from Sphyraena barracuda may possibly belong to this genus.

Bucephalopsis Diesing, 1855.

Bucephatinae in which the anterior end is provided with a simple globular muscular sucker. Type: B. gracilescens (Rud., 1819). G. tergestinum Stossich, 1883, should be included here, and probably a number of American forms.

Rhipidocotyle Diesing, 1858.

Bucephalinae in which the anterior end is provided with a feebly developed, shallow sucker surmounted by a fan-shaped hood. When this is contracted the anterior end appears square. Type: $R$. minima (Wagener, 1852), Nicoll, 1914 (=Gasterostomum triglae van Ben., 1870, Nicoll, 1909), includes also $R$. viperae (van Ben., 1870), Nicoll, 1914, and probably a number of species from American fishes (Linton, 1910, Figs. 217, 222, 223).

\section{Family BUCEPHALIDAE.}

Sub-Family Bucephalinae.

Genus BUCEPHALOPSIS (Diesing).

Bucephalopsis gracilescens (Rud.).

Lebour, 1908, pp. 18-21.

This common parasite of Lophius piscatorius was found in four out of five specimens of that fish. It occurred in the intestine and pyloric caeca, usually in large numbers. 


\section{Genus BUCEPHALUS Baer. \\ Bucephalus minimus (Stossich). $=$ Gasterostomum minimum Stossich, 1887, p. 96 .}

About two dozen specimens of a small Gasterostome were found in the intestine of Labrax lupus. They correspond in most respects with Stossich's description of Gasterostomum minimum from the same host, but the position of the testes and the extent of the uterus are different.

It is a small plump form reaching a length of a little over $1 \mathrm{~mm}$. The outline is oval and the maximum breadth is about half the length. The anterior sucker is terminal and is surrounded by a circle of six highly contractile tentacles. When extended these tentacles may be long and almost filiform. When completely retracted they are almost impossible to discern. In a semi-contracted state they appear as small, feshy, knob-like protuberances.

The ovary lies on the right side of the pharynx, which is situated about the middle of the body. The testes lie directly behind the pharynx. They are oblique and overlap each other considerably. The uterus fills up a large part of the body, extending forward as far as the level of the anterior sucker. The ova measure $\cdot 022-\cdot 024 \times \cdot 013-\cdot 015 \mathrm{~mm}$.

\section{Genus RHIPIDOCOTYLE Diesing. \\ Rhipidocotyle minima (Wagener). =Gasterotomum triglae (van Ben.), Nicoll.}

This species was met with in the intestine of the gurnards, Trigla pini, T. gurnardus, and T. hirundo. In the last-named it occurred also in the pyloric caeca. The parasite was not found in the half-dozen specimens of Trigla lyra which were examined.

The only note which may be added to my previous description (Nicoll, 1909 , pp. 23-4) is that in this species the excretory vesicle is of great length and extends a considerable distance in front of the ventral sucker. It even reaches further forward than the fundus of the stomach.

Several specimens of what appeared to be this species were met with in the intestine of Trachinus vipera. They agree in every particular except that the pharynx is situated further back. It is constantly behind the middle of the body, and may even be found as far back as the anterior end of the cirrus-pouch. Its relation to the other organs is consequently very variable. Sometimes it is on the level of the anterior testis. The only other noticeable feature is that the anterior sucker and the pharynx are less unequal in diameter than is the case in typical 
examples of $G$. triglae. In consequence of the great variation which undoubtedly occurs it is not thought advisable to regard this as a distinct species.

Rhipidocotyle viperae (van Ben.) (Fig. 4).

I am identifying as this species a few Gasterostomes which were obtained from the intestine of Trachinus draco. It is a form which resembles $G$. triglae in general appearance, but which differs from it in

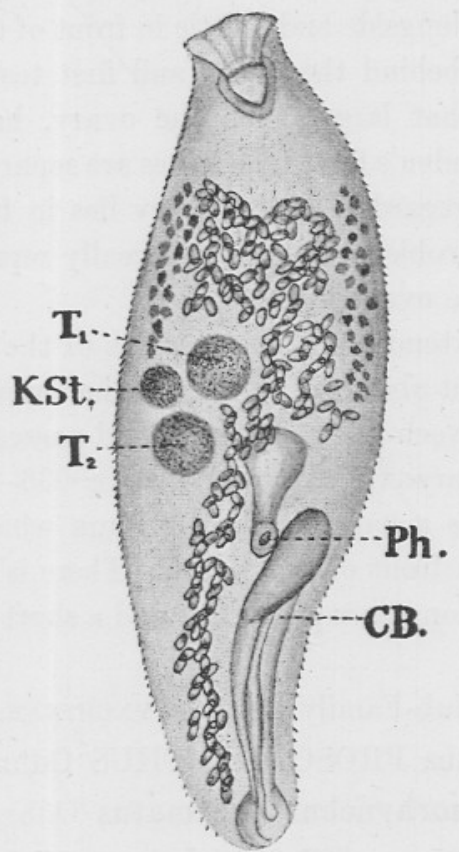

FIG, 4. - Rhipidocotyle viperae. Ventral view $\times 85$. C.B. Cirrus-pouch; K.St. Ovary; Ph. Pharynx; T. Testes. G. Roberts del.

having the genital glands arranged differently and in having a long and slender cirrus-pouch which extends forward to near the middle of the body.

The length of mature specimens is $\cdot 7-1 \cdot 2 \mathrm{~mm}$., and the maximum breadth in the middle of the body is about $4 \mathrm{~mm}$. The anterior end is square-cut and the posterior end pointed. The whole surface of the body is beset with minute spines.

At the anterior end there is a shallow sucker measuring, in the largest specimen, $\cdot 13 \mathrm{~mm}$. in diameter. Its musculature is very feebly developed. Surmounting the sucker is a five-rayed fan-shaped structure, closely 
resembling the corresponding structure in $R$. minimum. This is not represented in van Beneden's figure.

The pharynx (ventral sucker) is situated $.8 \mathrm{~mm}$. from the anterior end of the body. Its diameter is about $.055 \mathrm{~mm}$. The short intestinal sac is obscured by the uterus.

The genital glands lie close together on the right side a short distance in front of the mouth. The ovary is about $\cdot 6 \mathrm{~mm}$. from the anterior end of the body and lies close up against the side. It is globular and has a diameter of $\cdot 1 \mathrm{~mm}$. The testes are contiguous to it and to each other, the first testis lying alongside and a little in front of the ovary, the second testis lying directly behind the ovary and first testis. Both testes are globular and somewhat larger than the ovary, having a diameter of $.12 \mathrm{~mm}$. In van Beneden's figure the testes are separated by the pharynx, and what might be regarded as the ovary lies in front. It is possible, however, that that problematic structure really represents the intestinal sac, in which case the ovary is not shown.

The yolk glands extend along the margins of the body from the level of the ovary to a point about $\cdot 25 \mathrm{~mm}$. from the anterior end. The uterus fills up the space between the yolk glands and passes backwards between the testes and the pharynx. The ova measure $\cdot 036-\cdot 037 \times \cdot 018-\cdot 021 \mathrm{~mm}$.

The cirrus-pouch is a long slender structure which extends forwards to a short distance in front of the mouth. There is a fairly large simple vesicula seminalis, a long pars prostatica and a short ductus.

Sub-Family Prosorhynchinae.

Genus PROSORHYNCHUS Odhner.

Prosorhynchus squamatus Odhner.

Odhner, 1905, pp. 297-304 ; Lebour, 1908, pp. 21-3.

This was found on two occasions in the duodenum of Cottus bubalis, the first time in large numbers, the second time as a single specimen.

\section{Prosorhynchus aculeatus Odhner.}

Nicoll, 1910, pp. 350-2.

This common parasite of the conger was found in three out of four specimens of the fish.

Prosorhynchus crucibulum (Molin).

Nicoll, 1910, pp. 352-4.

This was found in association with $P$. aculeatus and quite as frequently. 
Prosorhynchus triglae sp. inq. (Fig. 5).

Single specimens of this species were found on two occasions, once in the intestine and once in the stomach of Trigla gurnardus. Both specimens were quite immature, so that it is impossible to give a complete description of the species, which appears to be hitherto unrecorded. It measures $2 \cdot 2-2 \cdot 4 \mathrm{~mm}$. in length and $.75 \mathrm{~mm}$. in maximum breadth. At the anterior end there is a wedge-shaped rostellum resembling that in

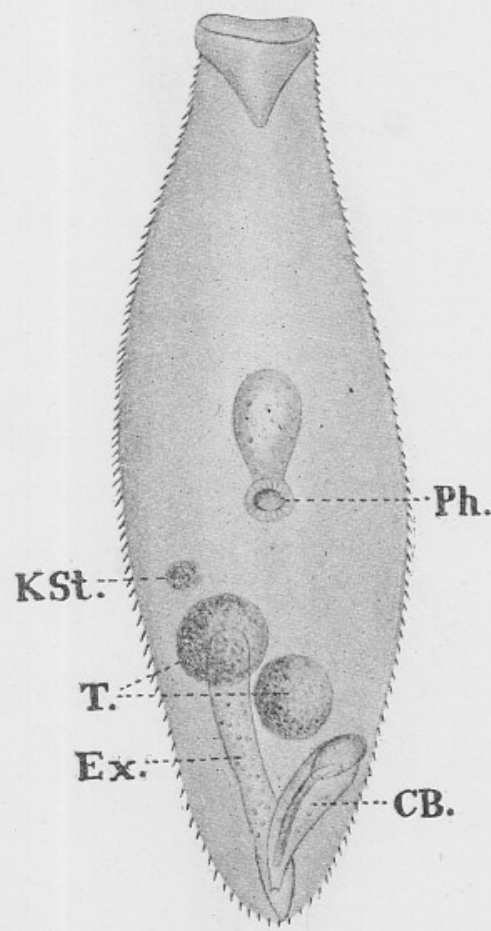

Fig. 5. - Prosorhynchus triglae. Ventral view $\times 40$. C.B. Cirrus-pouch; Ex. Excretory vesicle; K.St. Ovary ; Ph. Pharynx; T. Testes. G. Roberts del.

$P$. crucibulum (diameter $\cdot 3 \mathrm{~mm}$.). The small ventral sucker (pharynx) is situated nearly in the middle of the body (diameter $\cdot 1 \mathrm{~mm}$.).

The intestinal sac extends forwards and is not of very large size. The excretory vesicle extends about one-half or two-thirds the distance between the posterior end of the body and the pharynx.

The cirrus-pouch is about half the length of the excretory vesicle. The testes are fairly large, close together and nearly tandem. The posterior (left) testis is contiguous with the cirrus-pouch in one and displaced to the left in the other. 
The small ovary lies immediately in front of the anterior testis on the right side. The yolk glands were not distinct.

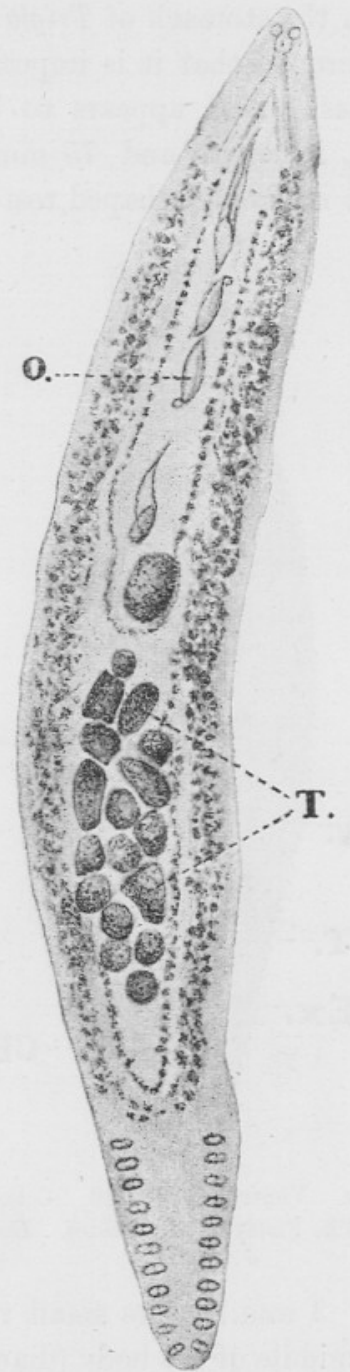

FiG. 6. - Microcotyle draconis. Ventral view $\times 25$ (Specimen from Aberdeen). O. Ora; T. Testes. M. Rhodes del.

\section{MONOGENEA.}

The number of ectotrematodes collected was not very large, and they were all, with perhaps one exception, common and well-known species. Axine belones, Octobothrium merlangi and Octocotyle scombri were found on the gills of Belone vulgaris, Gadus merlangus and Scomber scombrus 
respectively. Pseudocotyle squatinae was found on the skin of Rhina squatina, and Calicotyle Kroyeri was met with in the cloaca of the three rays, Raja circularis, $R$. maculata and $R$. clavata. A species of Microcotyle was obtained from the gills of Trachinus draco. Two specimens only were present, and they were not quite mature. Their posterior end was provided with seven suckers on each side. Some similar specimens were collected from the same host at Aberdeen (Fig. 6). They were larger and apparently fully mature. In them the posterior end had eleven pairs of suckers. I am unable to decide whether these two forms are identical or not, and whether both are identical with the Microcotyle draconis obtained by Briot (1904) from the same host. As Briot's work is not accessible to me I am unable to make any comparison of these forms. The probability is that my specimens are identical with those of Briot.

Descriptions of Calicotyle Kroyeri and Octobothrium merlangi are to be found by Lebour (1908, pp. 49 and 50). A description of Axine belones will be found by Scott (1911, p. 69).

\section{LIST OF FISHES EXAMINED AT PLYMOUTH, WITH THE TREMATODE PARASITES COLLECTED FROM THEM.}

1. Labrax lupus.

Cainocreadium labracis.

Intestine.

Acanthochasmus imbutiformis.

Intestine.

Bu ephalus minimus.

Intestine.

2. Serranus cabrilla.

Helicometra pulchella.

Intestine.

Lecithaster gibbosus.

Rectum.

3. Mullus barbatus.

Derogenes varicus.

Stomach.

4. Sparus centrodontus.

Steringotrema pagelli.

Intestine.

Zoonogenus vividus.

Rectum.

Derogenes varicus.

Stomach.

Hemiurus communis.

Stomach.

5. Trachurus trachurus.

Tergestia laticollis.

Rectum.

Derogenes varicus.

Stomach.

Lecithaster gibbosus.

Hemiurus communis.

Intestine.

Intestine. 
6. Capros aper.

Pharyngora bacillaris.

Derogenes varicus.

Hemiurus communis.

Hemiurus ocreatus.

7. Scomber scombrus.

Pharyngora bacillaris.

Hemiurus ocreatus.

Lecithocladium excisum.

Octocotyle scombri.

8. Zeus faber.

Stephanochasmus cesticillus.

Zoogonoides viviparus.

Derogenes varicus.

Lecithaster gibbosus.

Synaptobothrium caudiporum.

9. Trachinus draco.

Derogenoides ovacutus.

Derogenes varicus.

Rhipidocotyle viperae.

Microcotyle draconis (?).

10. Trachinus vipera.

Derogenes varicus.

Lecithaster gibbosus.

Rhipidocotyle minimum.

11. Lophius piscatorius.

Derogenes varicus.

Hemiurus communis.

Lecithochirium rufoviride.

Synaptobothrium caudiporum.

Bucephalopsis gracilescens.

12. Cottus bubalis.

Podocotyle atomon.

Derogenes varicus.

Hemiurus communis.

Prosorhynchus squamatus.

13. Agonus cataphractus.

Derogenes varicus.
Intestine.

Stomach.

Stomach.

Stomach.

Intestine.

Stomach.

Stomach.

Gills.

Intestine.

Rectum.

Stomach.

Rectum.

Stomach.

Stomach.

Stomach.

Intestine.

Gills.

Intestine.

Intestine.

Intestine.

Esophagus.

Stomach.

Stomach.

Stomach.

Intestine and coeca.

Intestine.

Stomach.

Stomach and intestine

Duodenum.

Caeca and intestine. 
14. Callionymus lyra.

Lebouria varia.

Intestine.

Zoogonoides viviparus.

Rectum.

Derogenes varicus.

Mouth.

15. Trigla pini.

Helicometra pulchella.

Caeca.

Derogenes varicus.

Stomach.

Lecithaster gibbosus.

Hemiurus communis.

Rhipidocotyle minima.

Phyllocotyle gurnardi.

Stomach.

Stomach.

Intestine.

Gills.

16. Trigla gurnardus.

Derogenes varicus.

Hemiurus communis.

Rhipidocotyle minima.

Prosorhynchus triglae.

Stomach.

Stomach.

Intestine.

Stomach and intestine.

17. Trigla hirundo.

Derogenes varicus.

Synaptobothrium caudiporum.

Rhopidocotyle minima.

Stomach and mouth.

Stomach and mouth.

Intestine and caeca.

18. Cyclopterus lumpus.

Pharyngora bacillaris.

Derogenes varicus.

Intestine and caeca.

Stomach.

19. Cyclogaster montagui.

Podocotyle atomon.

Intestine.

20. Gobius ruthensparri.

Podocotyle atomon.

Intestine.

21. Gobius paganellus.

Helicometra pulchella.

Hemiurus communis.

Intestine and stomach. Stomach.

22. Blennius gattorugine.

Helicometra pulchella.

Intestine and stomach.

Zoogonoides viviparus.

Monorchis monorchis.

Rectum and intestine.

Stomach.

23. Blennius ocellaris.

Steringotrema divergens.

Duodenum.

Zoogonoides viviparus.

Rectum.

Derogenes varicus.

Mouth. 
24. Blennius photis.

Peracreadium genu.

Helicometra pulchella.

Lecithochirium rufoviride (larva)

Synaptobothrium caudiporum (larva).

25. Centronotus gunnellus.

Podocotyle atomon.

26. Mugil chelo.

Haploporus benedeni.

Saccocoelium obesum.

27. Atherina presbyter.

(Podocotyle) atherinae.

Bacciger bacciger.

28. Gastraea spinachia.

Podocotyle atomon.

Podocotyle reflexa.

29. Lepadogaster gouanii.

Helicometra pulchella.

Hemipera ovocaudata.

Hemiurus communis.

30. Labrus berggylta.

Peracreadium genu.

Peracreadium commune.

Lebouria alacris.

Helicometra pulchella.

Lepidauchen stenostoma.

Synaptobothrium caudiporum (larva).

31. Labrus mixtus.

Helicometra pulchella.

32. Crenilabrus melops.

Peracreadium commune.

Lebouria alacris.

Synaptobothrium caudiporum (larva).
Intestine.

Intestine.

Encysted in viscera.

Encysted in viscera.

Intestine.

Intestine.

Intestine.

Intestine.

Stomach.

Intestine.

Intestine.

Intestine.

Stomach.

Rectum.

Rectum.

Intestine.

Intestine.

Intestine.

Intestine.

Encysted in intestinal wall.

Intestine.

Intestine.

Intestine.

Encysted in intestinal wall. 
33. Centrolabrus rupestris.

Lebouria alacris.

Helicometra pulchella.

Intestine.

Intestine.

34. Centrolabrus exoletus.

Lebouria alacris.

Intestine.

35. Gadus luscus.

Stephanochasmus caducus.

Derogenes varicus.

Hemiurus communis.

Intestine and coeca.

Stomach.

Stomach.

36. Gadus minutus.

Stephanochasmus caducus.

Caeca.

Derogenes varicus.

Stomach.

Hemiurus communis.

Stomach.

37. Gadus merlangus.

Podocotyle atomon.

Stephanochasmus pristis.

Pharyngora bacillaris.

Derogenes varicus.

Lecithaster gibbosus.

Hemiurus communis.

Hemiurus ocreatus.

Octobothrium merlangi.

Caeca.

Duodenum.

Caeca.

Stomach.

Intestine.

Stomach.

Stomach.

Gills.

38. Gadus pollachius.

Lepipapedon rachion.

Derogenes varicus.

Hemiurus communis.

Hemiurus ocreatus.

39. Molva molva.

Derogenes varicus.

Hemiurus communis.

40. Onos mustela.

Podocotyle reflexa.

41. Onos tricirratus.

Derogenes varicus.

Intestine.

Stomach.

Stomach.

Stomach.

Stomach.

Stomach.

Intestine, caeca and stomach.

Stomach.

42. Ammodytes lanceolatus.

Hemiurus communis.

Stomach. 
43. Bothus maximus.

Derogenes varicus.

Stomach.

44. Pleuronectes flesus.

Podocotyle atomon.

Derogenes varicus.

Intestine.

Intestine.

45. Pleuronectes limanda.

Steringotrema cluthense.

Duodenum.

Zoogonoides viviparus.

Derogenes varicus.

Rectum and intestine.

Stomach and intestine.

46. Pleuronectes microcephalus.

Steringotrema cluthense.

Duodenum.

Zoogonoides viviparus.

Rectum and intestine.

47. Pleuronectes platessa.

Zoogonoides viviparus.

Rectum.

48. Zeugopterus punctatus.

Helicometra pulchella.

Intestine.

Hemiurus communis.

Stomach.

49. Zeugopterus norvegicus.

Podocotyle atomon.

Lecithaster gibbosus.

Rectum.

Intestine.

50. Solea vulgaris.

Zoogonoides viviparus.

Derogenes varicus.

Intestine.

Stomach and intestine.

51. Solea variegata.

Zoogonoides viviparus.

Rectum and intestine.

52. Salmo trutta.

Bunodera nodulosa.

Intestine.

Derogenes varicus.

Stomach.

53. Clupea pilchardus.

Hemiurus ocreatus.

Stomach.

54. Belone vulgaris.

Axine belones.

Gills.

55. Anguilla vulgaris.

Podocotyle atomon.

Helicometra pulchella.

Intestine.

Lecithochirium rufoviride.

Intestine.

Stomach. 
56. Conger conger.

Helicometra pulchella.

Derogenes varicus.

Lecithochirium rufoviride.

Prosorhynchus aculeatus.

Prosorhynchus crucibulum.

57. Syngnathus acus.

Podocotyle syngnathi.

58. Nerophis aequoreus.

Podocotyle atomon.

Podocotyle syngnathi.

Hemiurus communis.

59. Siphonostoma typhle.

Podocotyle syngnathi.

Acanthochasmus imbutiformis (larva).

60. Raja circularis.

Calicotyle kroyeri.

61. Raja maculata.

Calicotyle kroyeri.

62. Raja clavata.

Calicotyle kroyeri.

63. Mustelus vulgaris.

Ptychogonimus megastomus.

64. Rhina squatina.

Pseudocotyle squatinae.
Intestine.

Stomach.

Stomach.

Intestine.

Intestine.

Intestine.

Intestine.

Intestine.

Intestine.

Intestine.

Encysted in gills.

Rectum.

Cloaca.

Rectum.

Stomach.

Skin. 


\section{REFERENCES.}

1. van Beneden, P. J. 1871. "Les Poissons des Côtes de Belgique, leurs parasites et leurs commensaux" in Mem. Acad. Roy. d. sc. de Belg., Bruxelles, XXXVIII, pp. 1-100.

2. Diesing, K. M. 1855. "Revision der Cercarieen" in Sitzungsber d. $k$. Akad. d. Wissenschaft, Math. Naturwissensch. kl., XV, pp. 377-40.

3. Diesing, K. M. 1858. "Revision der Myzhelminthen. Abt. Trematoden," ibid., XXXII, pp. 207-90.

4. JАСоBу, S. 1899. "Beiträge zur Kenntnis einiger Distomen," Archiv f. Naturgeschichte, LXVI, pp. 1-30.

5. JüGerskiöLd, L. A. 1900. " Ein neuer Typus von Copulationsorgan bei Distomum megastomum " in Centralbl. f. Balt. und Parasitenkunde, Abt. 1, XXVII, pp. 68-74.

6. Johnstone, J. 1906. "Internal Parasites and diseased conditions of fishes" in Trans. Biol. Soc. Liverpool, XX, pp. 151-85.

7. Johnstone, J. 1907. "Internal Parasites and diseased conditions of fishes" in Trans. Biol. Soc. Liverpool, XXI, pp. 170-203.

8. Johnstone, J. 1908. "Redescription of a Trematode Parasite, Allocreadium labracis (Dujardin) from the Bass" in Trans. Biol. Soc. Liverpool, XXII, pp. 44-53.

9. Lebour, M. V. 1908. "Fish Trematodes of the Northumberland Coast" in Northumberland Sea Fisheries Report for 1907, pp. 11-67.

10. Linton, E. 1910. "Helminth fauna of the Dry Tortugas. II Trematodes" in Publication No. 133 Carnegie Institute of Washington, 1910, pp. 11-98.

11. Looss, A. 1894. "Die Distomen unserer Fische und Frösche," Bibliotheca zoologica, 1894, Heft 16, pp. 1-296.

12. Looss, A. 1901. "Ueber die Fasciolidengenera Stephanochasmus, Acanthochasmus und einige andere" in Centralbl. f. Bakt. und Parasitenkunde, Abt. 1, XXIX, pp. 595-606, 628-34, 654-61.

13. Looss, A. 1902a. "Die Distomen unterfamilie der Haploporinae" in Arch. de Parasitologie, VI, pp. 129-43.

14. Looss, A. 1902b. "Zur Kenntnis der Trematoden-fauna des Triester Hafens II, Ueber Monorchis Montic. und Haplosplanchnus n.g." in Centralbl. f. Bakt. und Parasitenkunde, Abt. 1, Orig. XXXII, pp. 115-22.

15. Looss, A. 1907. "Beiträge zur Systematik der Distomen. Zur Kenntnis der Familie Hemiuridae" in Zoolog. Jahrbücher, Abt. f. Syst., XXVI, pp. 63-180.

16. NiCOLL, W. 1907. "A Contribution towards a knowledge of the Entozoa of British Marine Fishes, Part I," in Ann. Mag. Nat. Hist., Ser. 7, Vol. XIX, pp. 66-94. 
17. NicolL, W. 1909. "A contribution towards a knowledge of the Entozoa of British Marine Fishes, Part II," in Ann. Mag. Nat. Hist., Ser. 8, IV, pp. 1-25.

18. Nicoll, W. 1910. "On the Entozoa of Fishes from the Firth of Clyde " in Parasitology, III, pp. 322-59.

19. Nrcoll, W. 1912. "On two new Trematode Parasites from British Food Fishes" in Parasitology, V, pp. 197-202.

20. Nicold, W. 1913a. "New Trematode Parasites from Fishes of the English Channel" in Parasitology, V, pp. 238-46.

21. Nicoll, W. 1913b. "Trematode Parasites from Food Fishes of the North Sea" in Parasitology, VI, pp. 188-94.

22. Odhner, T. 1902a. "Mitteilungen zur Kenntnis der Distomen," I, in Centralbl. f. Bakt. und Parasitenkunde, Abt. 1, Orig. XXXI, pp. 58-69.

23. Odhner, T. 1902b. "Mitteilungen zur Kenntnis der Distomen," II, in Centralbl. f. Bakt. und Parasitenkunde, Abt. 1, Orig. XXXI, pp. 152-62.

24. ODHNER, T. 1905. "Die Trematoden des arktischen Gebietes" in Fauna Arctica, IV, pp. 291-372.

25. OdHner, T. 1911. "Zum naturlichen System der digenen Trematoden," III, in Zool. Anzeig., XXXVIII, pp. 97-117.

26. Scotr, T. 1911. "Notes on some Trematode Parasites of Fishes" in 28th Ann. Rept. Fishery Board Scotland, pp. 68-72.

27. Sтоssich, M. 1889. "Brani di elmintologia tergestina," VI, in Boll. Soc. Adriat. sc. Nat. Trieste, XI, pp. 1-8.

28. Wagener, G. R. 1852. "Enthelminthica No. 3; Ueber Distoma dimorphum Diesing, Distoma marginatum Rud." in Arch. f. Anat., Physiol. und Wissensch. Med., Berlin, 1852, pp. 555-69. 